\title{
Prevalence of hepatitis $C$ serum antibody in autoimmune diseases
}

\author{
Nancy Agmon-Levin a,b,1, Maya Ram ${ }^{\text {a,1 }}$, Ori Barzilai ${ }^{\mathrm{a}}$, Bat sheva Porat-Katz ${ }^{\mathrm{c}}$, Ronit Parikman ${ }^{\mathrm{a}}$, \\ Carlo Selmi ${ }^{\mathrm{d}}$, M. Eric Gershwin ${ }^{\mathrm{e}}$, Juan-Manuel Anaya ${ }^{\mathrm{f}}$, Pierre Youinou ${ }^{\mathrm{g}}$, Nicola Bizzaro ${ }^{\mathrm{h}}$, \\ Angela Tincani ${ }^{i}$, Athanasios G. Tzioufas ${ }^{\mathrm{j}}$, Ricard Cervera ${ }^{\mathrm{k}}$, Ljudmila Stojanovich ${ }^{1}$, Javier Martin ${ }^{\mathrm{m}}$, \\ Miguel Angel Gonzalez-Gay ${ }^{\mathrm{n}}$, Gabriele Valentini ${ }^{\mathrm{o}}$, Miri Blank ${ }^{\mathrm{a}}$, Marielle SanMarco ${ }^{\mathrm{p}}$, Blaž Rozman ${ }^{\mathrm{q}}$, \\ Stefano Bombardieri ${ }^{\mathrm{o}}$, Salvatore De Vita ${ }^{\mathrm{r}}$, Yehuda Shoenfeld ${ }^{\mathrm{a}, \mathrm{b}, \mathrm{s}, *}$ \\ ${ }^{a}$ Center for Autoimmune Diseases, Chaim Sheba Medical Center, Tel-Hashomer 52621, Israel \\ b Department of Medicine 'B', Chaim Sheba Medical Center, Tel-Hashomer 52621, Israel \\ ${ }^{\mathrm{c}}$ Faculty of Agricultural, Food and Environmental Quality Sciences, The Hebrew University of Jerusalem, Israel \\ ${ }^{\mathrm{d}}$ Department of Internal Medicine, IRCCS Istituto Clinico Humanitas, University of Milan, Italy \\ ${ }^{\mathrm{e}}$ Division of Rheumatology, Allergy and Clinical Immunology, University of California at Davis School of Medicine, Davis, CA, USA \\ ${ }^{\mathrm{f}}$ Center for Autoimmune Diseases research (CREA), Corporacion para Investigaciones Biologicas, Universidad del Rosario, Medellin, Colombia \\ ${ }^{\mathrm{g}}$ Laboratoire d'immunologie, Brest University Medical School Hospital, Brest, France \\ ${ }^{\mathrm{h}}$ Laboratorio di Patologia Clinica, Ospedale Civile, Tolmezzo, UD, Italy \\ ${ }^{\mathrm{i}}$ Rheumatology and Clinical Immunology Unit, University of Brescia, Brescia, Italy \\ ${ }^{\mathrm{j}}$ Department of Pathophysiology, School of Medicine, University of Athens, Greece \\ ${ }^{\mathrm{k}}$ Department of Autoimmune Diseases, Hospital Clínic, Barcelona, Catalonia, Spain \\ ${ }^{1}$ Bezhanijska Kosa University Medical Center, Belgrade University, Serbia \\ ${ }^{\mathrm{m}}$ Department of Internal Medicine, Division of Rheumatology, University of Pisa, Pisa, Italy \\ ${ }^{\mathrm{n}}$ Department of Rheumatology, Hospital Xeral-Calde, Lugo, Spain \\ ${ }^{\circ}$ Second University of Naples, Rheumatology Unit, Napoli, Italy \\ ${ }^{\mathrm{p}}$ Fédération Autoimmunité et Thrombose, Laboratoire d'Immunologie Hôpital de La Conception, Marseille, France \\ ${ }^{\mathrm{q}}$ Clinical Department of Rheumatology, University Medical Center Ljubljana, Slovenia \\ ${ }^{\mathrm{r}}$ Rheumatology Clinic, University of Udine, Udine, Italy \\ ${ }^{\mathrm{s}}$ Sackler Faculty of Medicine, Incumbent of the Laura Schwarz-Kip Chair for Research of Autoimmune Diseases, Tel-Aviv University, Israel
}

\section{A R T I C L E I N F O}

Article history:

Received 3 January 2009

Accepted 11 February 2009

\section{Keywords:}

Hepatitis-C

Autoimmune diseases

Autoantibodies

Cryoglobulinemia

Thyroid autoimmune diseases

Inflammatory bowel diseases

Pemphigus vulgaris

Antiphospholipids syndrome

\begin{abstract}
A B S T R A C T
Objective: To evaluate the prevalence of serum antibodies against hepatitis $C$ virus and other infectious agents in a large cohort of well-characterized patients with autoimmune diseases (AID).

Methods: We utilized 1322 sera from patients with 18 different AID and 236 sera from healthy controls from the same countries and with similar age and sex distribution. All sera were tested for the presence of serum anti-hepatitis $\mathrm{C}$ virus (HCV) antibodies as well as antibodies directed at other infectious agents and autoantibodies.

Results: Anti-HCV antibody was detected in 115/1322 (8.7\%) of patients with AID and $0.4 \%$ of matched healthy controls $(P<0.0001)$. The prevalence of anti-HCV antibody was significantly higher in $7 / 18$ different AID (i.e. cryoglobulinemia, mixed cryoglobulinemia pemphigus vulgaris, vasculitis, secondary anti-phospholipid syndrome, Hashimoto's thyroiditis, and inflammatory bowel disease) compared to controls. Patients with AID and serum anti-HCV positivity had an increased prevalence of antibodies against hepatitis B virus, Toxoplasma gondii and Cytomegalovirus as opposed to a lower frequency of serum autoantibodies.
\end{abstract}

Abbreviations: ANA, anti-nuclear antibody; RF, rheumatoid factor; anti-SMA, anti-smooth muscle antibodies; aCL, anti-cardiolipin antibodies; anti-LKM1, anti-liver kidney

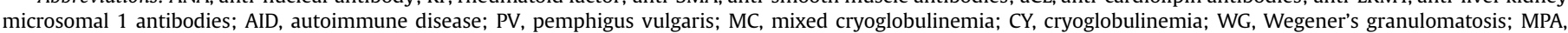

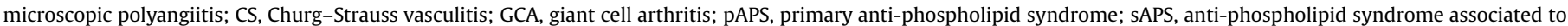

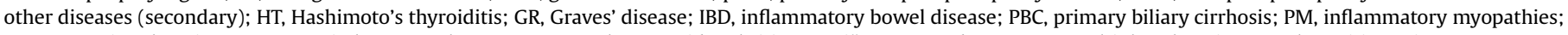

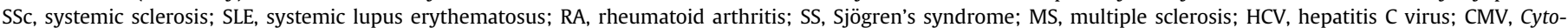
megalovirus; EBV, Epstein-Barr virus; VCA, viral capsid antigen; NA, nuclear antigen; EA, early antigen.

* Corresponding author at: Department of Medicine 'B' , Chaim Sheba Medical Center, Tel-Hashomer 52621, Israel. Tel.: +972 3 5302652. fax: +972 3 5352855.

E-mail address: shoenfel@post.tau.ac.il (Y. Shoenfeld).

1 Both authors have equally contributed to this paper. 
Conclusions: The enhanced prevalence of anti-HCV serum antibodies in AID may suggest a role for HCV in tolerance to breakdown, similarly to its established role in mixed cryoglobulinemia. This immune mediated effect does not rule out the role of other infectious agents.

(c) 2009 Published by Elsevier Ltd.

\section{Introduction}

The link between infectious diseases and autoimmune diseases (AID) has been repeatedly suggested based mostly on epidemiological and experimental data [1-4]. Various infectious agents are known to trigger tolerance breakdown, as in the case of hepatitis $C$ virus (HCV) in specific conditions [2,5]. Chronic liver disease associated with HCV affects $70-90 \%$ of infected subjects [6] and is frequently associated with extra hepatic manifestations [7]. The worldwide prevalence of HCV chronic infection is estimated to range between 2 and 3\% of the general population [8,9]. Indeed, extra hepatic manifestations of chronic HCV-infection [10] include autoimmune phenomena [11] and hematopoietic malignancy [12]. Among the former, it is not uncommon to detect serum antinuclear antibodies (ANA), cryoglobulins, rheumatoid factor (RF), anti-smooth muscle antibodies (SMA), anti-cardiolipin (aCL), antiliver kidney microsomal 1 (LKM1), and anti-thyroid antibodies [13-19], along with overt autoimmunity (as in the case of cryoglobulinemia) or variants of AID (i.e. Sjögren-like syndrome) $[13,15,20,21]$.

The mechanisms linking HCV with autoimmunity are unclear. $\mathrm{HCV}$ targets hepatocytes but can also replicate in other cells, such as lymphocytes [14] particularly B-cells [7,8,22]. Studies from our group [19] and others [23-25] demonstrated an increased level of B-lymphocyte activating factor (BAFF), a B-cell's survival factor, in chronic HCV-infection and suggest that B-cells activation and increased survival might play a role in HCV-associated autoimmunity. Other proposed mechanisms include the potential of HCV to induce auto-reactive CD8+T cells by molecular mimicry [26], the induction of high levels of endogenous IFN $\alpha$ [27], direct viral invasion and bystander activation [14,28,29].

Several authors have evaluated the prevalence of AID in HCVinfection using case-control studies, with conflicting results $[11,21,27,28,30-33]$. We herein report a complementary approach that investigated a large series of patients with defined AID for the prevalence of anti-HCV-antibodies as well as antibodies directed at other infectious agents and autoantigens. Our data support a significantly higher prevalence of serum anti-HCV antibody in patients with autoimmune diseases compared to healthy controls.

\section{Subjects and methods}

\subsection{Subjects}

Sera from 1322 patients with 18 different AID were collected from referral centers in Europe and Latin America and all patients fulfilled the international criteria for each specific disease while patients with more than one AID were excluded with the exception of sAPS. The European group of patients included patients with mixed cryoglobulinemia, cryoglobulinemia, pemphigus vulgaris $(\mathrm{PV})$, vasculitis [including Wegener's granulomatosis (WG), microscopic polyangiitis (MPA) and Churg-Strauss vasculitis (CS)], giant cell arthritis (GCA), primary anti-phospholipid syndrome (pAPS) and APS secondary to other diseases (sAPS), Hashimoto's thyroiditis (HT), Graves' disease (GD), inflammatory bowel disease (IBD), primary biliary cirrhosis (PBC), inflammatory myopathies (PM), and systemic sclerosis (SSc). The Latin American group included patients with systemic lupus erythematosus (SLE), rheumatoid arthritis (RA), Sjögren's syndrome (SS), and multiple sclerosis (MS). Control sera were obtained from 236 healthy subjects (97 from Europe, 139 from Latin America) of similar age and sex distribution ( $37 \pm 10$ years of age, $82 \%$ females) compared to patients. The study received approval of the local ethics committees and fulfilled the ethical guidelines of the most recent declaration of Helsinki (Edinburgh, 2000).

\subsection{Serum markers of infection and autoantibodies}

Sera from patients and controls were tested for anti-HCV (recombinant hepatitis C virus antigen: c22-3, c200 and NS5) using the HCV encoded antigen ORTHO HCV Version 3.0 ELISA test system (Johnson \& Johnson, Bio-Rad, Hercules, CA, USA) according to the manufacturer's protocol. Briefly, sera were added at dilution of 1:21 to hepatitis C recombinant c22-3, c200 and NS5 antigen-coated ELISA plates and the binding was detected by anti-human-IgGperoxidase and appropriate substrate. Positive results were calculated according to the manufacturer's equations for cut-off value determination.

Antibodies to hepatitis B virus (HBV) and Helicobacter pylori were tested using MONOLISA anti-HBc plus commercial kit and MONOLISA pylori - IgG commercial kit (Bio-Rad, Hercules, CA), respectively, according to the manufacturer's instructions. Antibodies directed at rubella, toxoplasma, Cytomegalovirus (CMV), Epstein-Barr virus (EBV) and Treponema pallidum were tested alongside a panel of autoantibodies using the Bio-Rad BioPlex 2200 (Bio-Rad) as described elsewhere [1,34]. Briefly, the BioPlex 2200 is a fully automated random-access analyzer built on a synthesis of multiplex, magnetic beads and flow cytometry technologies. At the core of the technology there are 25 different populations of $8-\mu \mathrm{m}$ magnetic beads, which are dyed with two fluorophores for classification purposes. The amount of antibody bound to the bead was determined by fluorescence analysis; raw data were subsequently converted to the fluorescence ratio using a pre-dyed internal normalizer the detector signal. Elevated titers were determined as above the cut-off of 2 standard deviations from the normal control group.

\subsection{Statistical analysis}

Continuous variables are expressed as mean \pm standard deviation. For purpose of comparisons, Fisher's exact test and the Chisquare test were used for categorical variable while the $t$-test and the ANOVA test were used for $N \geq 20$ in the presence of continuous variables. In the case of non-parametric variables the KruskalWallis test was used. $P$ values $\leq 0.003$ were considered as statistically significant following Bonferroni correction for multiple testing.

\section{Results}

\subsection{Serum HCV antibody prevalence}

Anti-HCV antibodies were found in 115/1322 (8.7\%) patients with AID while detected in 0/97 European and 1/139 Latin American 
controls leading to a cumulative $0.4 \%$ prevalence in the whole control group. Of note, patients with autoimmunity and HCVinfection were more frequently men (32\% vs. $18 \%$ compared with controls, $P=0.04)$ and older $(62 \pm 14$ vs. $37 \pm 10$ years of age; $P<0.0001$ compared with controls). When patients were arrayed according to their clinical subgroups, the prevalence of serum antiHCV antibodies was significantly higher $(P \leq 0.003)$ in $7 / 18$ autoimmune diseases (i.e. cryoglobulinemia, mixed cryoglobulinemia, PV, vasculitis, sAPS, Hashimoto's thyroiditis, IBD) (Fig. 1 and Table 1). In particular, 37 patients with IBD from Italy manifested a $13.5 \%$ prevalence of serum anti-HCV $(P=0.0002$ compared to controls).

\subsection{Serum antibodies to other infectious agents and anti-HCV in patients with AID}

The prevalence of antibodies to seven other infectious agents was compared between patients with AID $(N=115)$ and without $(N=1207)$ anti-HCV antibodies (Table 2$)$. Among patients with autoimmune diseases and anti-HCV antibodies 31\% had anti-HBV core antibodies compared to $10 \%$ of patients without anti-HCV positivity $(P<0.0001)$. Similarly, significantly higher rates of antitoxoplasma and anti-CMV antibodies were observed in patients with antibodies to HCV while no differences were observed between the two groups for other antibodies against infectious agents.

\subsection{Serum autoantibodies and anti-HCV in patients with AID}

The prevalence of serum autoantibodies in patients with AID arrayed according to their anti-HCV antibody status is illustrated in Table 3. Autoantibodies associated with vasculitis (i.e. anti-GBM, anti-MPO and anti-PR-3) and gastrointestinal diseases [i.e. antigliadin antibodies, anti-Saccharomyces cerevisiae (ASCA) and antitissue transglutaminase (TTG)] were detected in equal percentages among patients with or without serum anti-HCV antibodies. Similarly, autoantibodies associated with thrombophilia (i.e. anti-

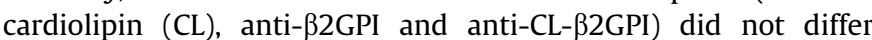
between groups, yet we note a higher prevalence of anti-CL in patients with anti-HCV antibodies (6\% vs. $1.5 \% ; P=0.007)$. Patients with autoimmune diseases and anti-HCV reactivity manifested a lower frequency of serum anti-nuclear autoantibodies (ANA)

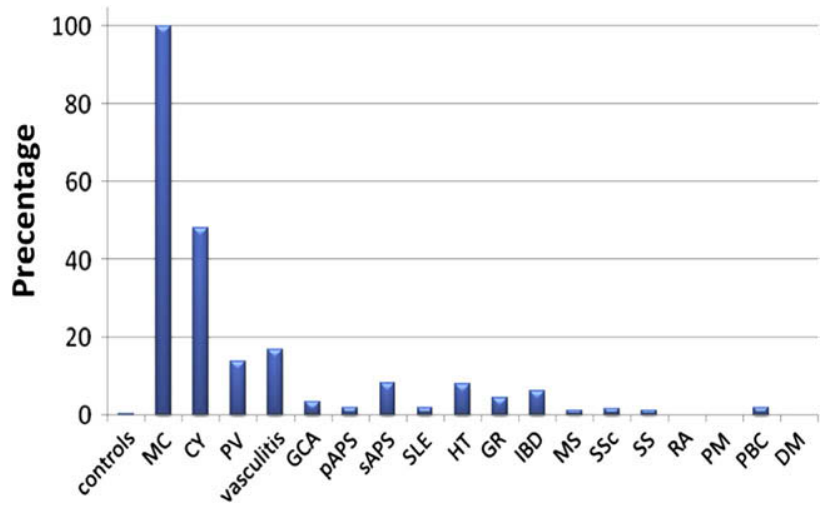

Fig. 1. Prevalence of anti-HCV antibodies in sera from patients with autoimmune diseases and healthy controls. Abbreviations: CY - cryoglobulinemia; MC - mixed cryoglobulinemia; PV - pemphigus vulgaris; sAPS - secondary APS; HT - Hashimoto's thyroiditis; IBD - inflammatory bowel disease; GR - Graves' disease; pAPS - antiphospholipid syndrome; PBC - primary biliary cirrhosis; SLE - systemic lupus erythematosus; MS - multiple sclerosis; SSc - systemic sclerosis; SS - Sjögren's syndrome; RA - rheumatoid arthritis; PM - inflammatory myopathies; vasculitis [i.e. Wegener's granulomatosis (WG), microscopic polyangiitis (MPA) and Churg-Strauss vasculitis (CS)]; GCA - giant cell arthritis; DM - diabetes mellitus.
Table 1

Prevalence of anti-HCV antibodies in 1322 serum samples of patients with different autoimmune diseases and healthy controls. $P$ values in the comparison with healthy controls are illustrated.

\begin{tabular}{lrll}
\hline & $N$ & Anti-HCV positive & $P$ value \\
\hline All patients with autoimmunity & $\mathbf{1 3 2 2}$ & $\mathbf{1 1 5}(\mathbf{8 . 7 \% )}$ & $<\mathbf{0 . 0 0 0 1}$ \\
Mixed cryoglobulinemia & 39 & $39(100 \%)$ & $\mathbf{< . 0 0 0 1}$ \\
Cryoglobulinemia & 77 & $36(47 \%)$ & $<\mathbf{0 . 0 0 0 1}$ \\
Pemphigus vulgaris & 29 & $4(14 \%)$ & $\mathbf{0 . 0 0 2}$ \\
Vasculitis (WG, MPA, CS) & 24 & $4(17 \%)$ & $\mathbf{0 . 0 0 0 2}$ \\
Giant cell arthritis & 29 & $1(3 \%)$ & NS \\
Primary APS & 97 & $2(2 \%)$ & NS \\
Secondary APS & 61 & $5(8 \%)$ & $<\mathbf{0 . 0 0 2}$ \\
Systemic lupus erythematosus & 108 & $2(2 \%)$ & NS \\
Hashimoto's thyroiditis & 100 & $8(8 \%)$ & $\mathbf{0 . 0 0 0 3}$ \\
Graves' disease & 87 & $4(5 \%)$ & 0.02 \\
Inflammatory bowel disease & 98 & $6(6 \%)$ & $\mathbf{0 . 0 0 3}$ \\
Multiple sclerosis & 98 & $1(1 \%)$ & NS \\
Systemic sclerosis & 77 & 0 & NS \\
Sjögren's syndrome & 78 & $1(1 \%)$ & NS \\
Rheumatoid arthritis & 95 & 0 & NS \\
Inflammatory myopathies & 76 & 0 & NS \\
Primary biliary cirrhosis & 60 & $1(2 \%)$ & NS \\
Diabetes mellitus & 88 & 0 & NS \\
\hline
\end{tabular}

$\mathrm{P} \leq 0.003$ was considered statistically significant; $\mathrm{NS}=$ not significant.

compared with anti-HCV negative patients (29\% vs. $47 \%$ $P=0.0002$ ). In particular, anti-SmRNP antibodies were significantly lower in patients with anti-HCV antibodies and a similar trend was observed for anti-dsDNA, anti-chromatin, anti-Smith, and anti-SSA antibodies.

\section{Discussion}

We report that serum anti-HCV antibodies are found in $8.7 \%$ of patients with AID, being associated with male gender and older age in agreement with former studies [35,36]. The prevalence of antiHCV antibodies in the general European and Latin American population ranges between 0.5 and $2.5 \%[8,9,37,38]$ compared to $0.4 \%$ in our healthy control group. This discrepancy may be secondary to the younger age of our control group which does not account for the higher prevalence at older ages (i.e. the cohort effect of HCV epidemiology) and is thus not representative of the general population.

We observed several associations between HCV reactivity and specific AID. First, our data confirm the association between HCV and cryoglobulinemia or mixed cryoglobulinemia $[25,31,39,40]$. In fact, cryoglobulins are detected in $40-60 \%$ of patients with chronic HCV-infection [41] and overt cryoglobulinemia has been reported in up to $56 \%$ of them according to their genetic variability

Table 2

Prevalence of serum antibodies against different infectious agents in 1322 patients with autoimmune diseases arrayed according to their anti-HCV status.

\begin{tabular}{llll}
\hline $\begin{array}{l}\text { Anti-infectious agents } \\
\text { antibodies }\end{array}$ & $\begin{array}{l}\text { Anti-HCV positive } \\
(N=115)\end{array}$ & $\begin{array}{l}\text { Anti-HCV negative } \\
(N=1207)\end{array}$ & $P$ value \\
\hline HBV core antigen & $31 \%$ & $10.3 \%$ & $<\mathbf{0 . 0 0 0 1}$ \\
Helicobacter pylori & $45 \%$ & $56 \%$ & NS \\
Toxoplasma gondii & $64 \%$ & $48 \%$ & $\mathbf{0 . 0 0 2}$ \\
Rubella & $90 \%$ & $91 \%$ & NS \\
$\begin{array}{l}\text { Cytomegalovirus } \\
\text { Treponema pallidum }\end{array}$ & $94 \%$ & $83 \%$ & $\mathbf{0 . 0 0 2}$ \\
$\begin{array}{l}\text { Epstein-Barr - Viral capsid } \\
\quad \text { antigen }\end{array}$ & $93 \%$ & $1.7 \%$ & NS \\
$\begin{array}{l}\text { Epstein-Barr -Nuclear } \\
\quad \text { antigen }\end{array}$ & $94 \%$ & $94 \%$ & NS \\
Epstein-Barr -Early antigen & $24 \%$ & $93 \%$ & NS \\
\hline
\end{tabular}

$\mathrm{P} \leq 0.003$ was considered statistically significant; $\mathrm{NS}=$ not significant. 
Table 3

Prevalence of autoantibodies in 1322 patients with autoimmune diseases in regard to the presence (no. 115) or absence (no. 1207) of anti-HCV-reactivity.

\begin{tabular}{|c|c|c|c|}
\hline Autoantibodies & $\begin{array}{l}\text { Anti-HCV positive } \\
(N=115)\end{array}$ & $\begin{array}{l}\text { Anti-HCV negative } \\
(N=1207)\end{array}$ & $P$ value \\
\hline \multicolumn{4}{|l|}{ Vasculitis associated: } \\
\hline $\begin{array}{l}\text { Glomerular basement } \\
\text { membrane }\end{array}$ & 0 & 0 & NS \\
\hline Myeloperoxidase (MPO) & $1 \%$ & $2 \%$ & NS \\
\hline Proteinase-3 (PR-3) & $3 \%$ & $1.5 \%$ & NS \\
\hline \multicolumn{4}{|c|}{ Gastrointestinal associated IgG } \\
\hline Gliadin & $6 \%$ & $10.5 \%$ & NS \\
\hline Tissue transglutaminase & $3 \%$ & $3.6 \%$ & NS \\
\hline Saccharomyces cerevisiae & $6 \%$ & $6 \%$ & NS \\
\hline \multicolumn{4}{|c|}{ Thrombophilia associated IgG } \\
\hline Cardiolipin & $6 \%$ & $1.5 \%$ & 0.007 \\
\hline B2GPI & $11 \%$ & $15 \%$ & NS \\
\hline CL-B2 & $8 \%$ & $5 \%$ & NS \\
\hline Anti-nuclear antibodies & $29 \%$ & $47 \%$ & 0.0002 \\
\hline dsDNA & $16 \%$ & $25 \%$ & 0.05 \\
\hline Chromatin & $12 \%$ & $25 \%$ & 0.02 \\
\hline RNP & $4 \%$ & $8 \%$ & NS \\
\hline Smith & $1 \%$ & $6 \%$ & 0.06 \\
\hline SmRNP & 0 & $8 \%$ & 0.0001 \\
\hline SS-A & $8 \%$ & $17 \%$ & 0.02 \\
\hline SS-B & $3 \%$ & $7 \%$ & NS \\
\hline Scl70 & $1 \%$ & $4 \%$ & NS \\
\hline Jo-1 & 0 & $1 \%$ & NS \\
\hline Centromere & $3 \%$ & $6.6 \%$ & NS \\
\hline Ribosomal-P & 0 & $2.4 \%$ & NS \\
\hline
\end{tabular}

$\mathrm{P} \leq 0.003$ was considered statistically significant; $\mathrm{NS}=$ not significant.

$[21,42,43]$. An association of HLA-DR11 phenotype with type II MC in patients with chronic HCV was reported, whereas HLA-DR7 appeared to protect $\mathrm{HCV}$-infected patients from the development of MC [44]. Moreover, current treatments for HCV ameliorate and may cure mixed cryoglobulinemia [43]. A suggested mechanism for this association is that HCV chronically stimulates B-cell polyclonal proliferation from which a monoclonal population may emerge [45] and mixed cryoglobulinemia ultimately reflects the polyclonal and monoclonal expansion of B-cells producing IgM with rheumatoid factor activity [41]. The association between other vasculitides and HCV has been reported by Lidar et al. [46] following the current study, showing a higher prevalence of anti-HCV positivity in patients with Wegener's granulomatosis.

Second, we observed a statistically significant association between anti-HCV antibodies and HT and to a minor degree with GD. Anti-thyroid antibodies are reported in $6-48 \%$ of patients with chronic HCV-infection [27,47] while increased prevalence of overt thyroid disorder (mainly hypothyroidism caused by autoimmune thyroiditis) was reported $[11,48,49]$ despite conflicting evidence $[27,50]$. Of note, HCV was documented in the thyroid gland [43] and it was also demonstrated that HCV envelope glycoprotein E2 can bind directly to thyroid cells and activate a cascade of signaling leading to cytokine [29] and chemokines [40] production. Furthermore, high levels of endogenous IFN $\alpha$ are induced by the virus and may also be involved in the appearance of thyroid autoimmunity in genetically predisposed subjects [27,51,52] while exogenous IFN $\alpha$ (i.e. anti-HCV therapy) may also induce the development of HT or GD in $5-12 \%$ [11,53]. Third, we found a significantly higher prevalence (14\%) of anti-HCV antibodies in sera from patients with pemphigus vulgaris, in contrast with previous reports $[54,55]$. To evaluate whether this observation is merely stochastic or possibly associated with anti-HCV treatment, a prospective study of a larger number of patients is warranted. Fourth, although many infectious agents were found to be associated with APS [56-58], we failed to observe an association between the presence of anti-HCV antibodies and pAPS, in agreement with previous studies $[16,59]$. However, $8 \%$ of patients with sAPS had detectable anti-HCV, similar to reported associations between HCV and atypical APS or catastrophic APS [60,61]. Thus, an association of HCV with certain features of APS might be suggested. Fifth, an association between IBD and HCV-infection has been reported in patients of Italian origin with Crohn's disease [62] while we have reported a prevalence of $6 \%$ following this study [63]. Of note, Italian patients with Crohn's disease included in our study manifested a striking prevalence of anti-HCV antibodies (13.5\%). Whether invasive procedures (i.e. endoscopy and surgery) [62] or $\mathrm{HCV}$-infection and treatment play a role in this association remain to be determined $[63,64]$. Lastly, the absence of associations between HCV and Sjögren's syndrome, SLE, and systemic sclerosis is somewhat surprising [42,47]. In the case of Sjögren's syndrome, we should note that the current diagnostic criteria include the lack of HCV-infection [65].

In our series, patients with anti-HCV antibodies and autoimmune diseases also had a higher frequency of serum antibodies against other infectious agents. In particular, 30\% of AID and anti$\mathrm{HCV}$ also manifest anti-HBV core antibodies compared with $10 \%$ of those without $\mathrm{HCV}$ reactivity. The co-existence of $\mathrm{HBCAb}$ and antiHCV antibodies is not uncommon $[9,66,67]$ as both viruses share major risk factors [68]. Co-infection with both viruses increases the progression of liver disease and complicates its treatment [68-71]. The role of toxoplasmosis in the pathogenesis of AID is unclear. In a previous study we reported an association between toxoplasmosis and several autoimmune diseases as thyroid diseases, vasculitides and PBC $[63,64,72]$ but not with SLE, rheumatoid arthritis and multiple sclerosis (unpublished data). On the contrary, the role of Cytomegalovirus had been extensively studied, and this virus was found to be associated with several autoimmune diseases [1].

The occurrence of serum autoantibodies in HCV-infected patients has been extensively studied, and an increased prevalence of anti-nuclear, anti-cardiolipin, anti-smooth muscle and antithyroglobulin antibodies was reported as compared with uninfected controls, alongside high levels of cryoglobulins and rheumatoid factor $[28,33,73,74]$. Anti-nuclear antibodies have been detected in $10-30 \%$ of HCV-infected patients and their presence correlates with older age $[75,76]$. Our observation shows that lower prevalences of specific autoantibodies are associated with anti-HCV reactivity in patients with autoimmune diseases are not unexpected. As an example, a lower prevalence of anti-SSA and anti-SSB is characteristic of HCV-associated Sjögren's syndrome, and the absence of anti$\mathrm{CCP}$ is typical of HCV-associated arthritis.

In conclusion, in line with the many interactions between infectious agents and autoimmunity [77] we have found anti-HCV antibodies to be significantly associated with cryoglobulinemia and thyroid autoimmune disease, in both of which HCV may play a pathogenic role. We have also found an association between HCV sero-reactivity and APS associated to other diseases, IBD, Wegener's granulomatosis and a possible novel association with pemphigus vulgaris. These associations might support a role of HCV in the pathogenesis of these AID or an increased susceptibility to HCVinfection in certain patients with AID. Large prospective studies are awaited to confirm the proposed associations.

\section{References}

[1] Barzilai O, Sherer Y, Ram M, Izhaky D, Anaya JM, Shoenfeld Y. Epstein-Barr virus and cytomegalovirus in autoimmune diseases: are they truly notorious? A preliminary report. Ann N Y Acad Sci 2007;1108:567-77.

[2] Shoenfeld Y, Zandman-Goddard G, Stojanovich L, et al. The mosaic of autoimmunity: hormonal and environmental factors involved in autoimmune diseases-2008. Isr Med Assoc J 2008;10(1):8-12.

[3] Fairweather D, Kaya Z, Shellam GR, Lawson CM, Rose NR. From infection to autoimmunity. J Autoimmun 2001;16(3):175-86. 
[4] Fujinami RS. Can virus infections trigger autoimmune disease? J Autoimmun 2001;16(3):229-34.

[5] Bach JF. Infections and autoimmune diseases. J Autoimmun 2005;25(Suppl):74-80.

[6] Ramos-Casals M, De Vita S, Tzioufas AG. Hepatitis C virus, Sjögren's syndrome and B-cell lymphoma: linking infection, autoimmunity and cancer. Autoimmun Rev 2005;4(1):8-15.

[7] Lauer GM, Walker BD. Hepatitis $C$ virus infection. $N$ Engl J Med 2001;345(1):41-52.

[8] Craxi A, Laffi G, Zignego AL. Hepatitis C virus (HCV) infection: a systemic disease. Mol Aspects Med 2008;29(1-2):85-95.

[9] Shepard CW, Finelli L, Alter MJ. Global epidemiology of hepatitis C virus infection. Lancet Infect Dis 2005;5(9):558-67.

[10] Modi AA, Liang TJ. Hepatitis C: a clinical review. Oral Dis 2008;14(1):10-4.

[11] Zignego AL, Ferri C, Pileri SA, Caini P, Bianchi FB. Extrahepatic manifestations of Hepatitis $C$ Virus infection: a general overview and guidelines for a clinical approach. Dig Liver Dis 2007;39(1):2-17.

[12] Giordano TP, Henderson L, Landgren O, et al. Risk of non-Hodgkin lymphoma and lymphoproliferative precursor diseases in US veterans with hepatitis C virus. Jama 2007;297(18):2010-7.

[13] Ahmed MM, Berney SM, Wolf RE, et al. Prevalence of active hepatitis C virus infection in patients with systemic lupus erythematosus. Am J Med Sci 2006;331(5):252-6.

[14] Ferri S, Muratori L, Lenzi M, Granito A, Bianchi FB, Vergani D. HCV and autoimmunity. Curr Pharm Des 2008;14(17):1678-85.

[15] McMurray RW, Elbourne K. Hepatitis C virus infection and autoimmunity. Semin Arthritis Rheum 1997;26(4):689-701.

[16] Sene D, Piette JC, Cacoub P. Antiphospholipid antibodies, antiphospholipid syndrome and infections. Autoimmun Rev 2008;7(4):272-7.

[17] Bianchi FB, Muratori P, Granito A, Pappas G, Ferri S, Muratori L. Hepatitis C and autoreactivity. Dig Liver Dis 2007;39(Suppl. 1):S22-4.

[18] Agarwal N, Handa R, Acharya SK, Wali JP, Dinda AK, Aggarwal P. A study of autoimmune markers in hepatitis $\mathrm{C}$ infection. Indian J Med Res 2001;113:170-4.

[19] Toubi E, Gordon S, Kessel A, et al. Elevated serum B-Lymphocyte activating factor (BAFF) in chronic hepatitis $C$ virus infection: association with autoimmunity. J Autoimmun 2006;27(2):134-9.

[20] Ganne-Carrie N, Medini A, Coderc E, et al. Latent autoimmune thyroiditis in untreated patients with HCV chronic hepatitis: a case-control study. J Autoimmun 2000;14(2):189-93.

[21] Lormeau C, Falgarone G, Roulot D, Boissier MC. Rheumatologic manifestations of chronic hepatitis C infection. Joint Bone Spine 2006;73(6):633-8.

[22] Landau DA, Saadoun D, Calabrese LH, Cacoub P. The pathophysiology of HCV induced B-cell clonal disorders. Autoimmun Rev 2007;6(8):581-7.

[23] Sene D, Limal N, Ghillani-Dalbin P, Saadoun D, Piette JC, Cacoub P. Hepatitis C virus-associated B-cell proliferation-the role of serum B lymphocyte stimulator (BLyS/BAFF). Rheumatology (Oxford) 2007;46(1):65-9.

[24] Landau DA, Rosenzwajg M, Saadoun D, Klatzmann D, Cacoub P. The BLyS/BAFF receptor-ligand system in HCV induced B-cell clonal disorders. Ann Rheum Dis 2008.

[25] De Vita S, Quartuccio L, Fabris M. Hepatitis C virus infection, mixed cryoglobulinemia and BLyS upregulation: targeting the infectious trigger, the autoimmune response, or both? Autoimmun Rev 2008;8(2):95-9.

[26] Kammer AR, van der Burg SH, Grabscheid B, et al. Molecular mimicry of human cytochrome $\mathrm{P} 450$ by hepatitis $\mathrm{C}$ virus at the level of cytotoxic T cell recognition. J Exp Med 1999;190(2):169-76.

[27] Antonelli A, Ferri C, Fallahi P, et al. Thyroid disorders in chronic hepatitis C virus infection. Thyroid 2006;16(6):563-72.

[28] Buskila D, Shnaider A, Neumann L, et al. Musculoskeletal manifestations and autoantibody profile in 90 hepatitis $C$ virus infected Israeli patients. Semin Arthritis Rheum 1998;28(2):107-13.

[29] Akeno N, Blackard JT, Tomer Y. HCV E2 protein binds directly to thyroid cells and induces IL-8 production: A new mechanism for HCV induced thyroid autoimmunity. J Autoimmun 2008;31(4):339-44.

[30] Hadziyannis SJ. The spectrum of extrahepatic manifestations in hepatitis C virus infection. J Viral Hepat 1997;4(1):9-28.

[31] Vassilopoulos D, Calabrese LH. Rheumatic manifestations of hepatitis C infection. Curr Rheumatol Rep 2003;5(3):200-4

[32] Pawlotsky JM, Roudot-Thoraval F, Simmonds P, et al. Extrahepatic immunologic manifestations in chronic hepatitis $C$ and hepatitis $C$ virus serotypes. Ann Intern Med 1995;122(3):169-73.

[33] Cacoub P, Renou C, Rosenthal E, et al. Extrahepatic manifestations associated with hepatitis C virus infection. A prospective multicenter study of 321 patients. The GERMIVIC. Groupe d'Etude et de Recherche en Medecine Interne et Maladies Infectieuses sur le Virus de l'Hepatite C. Medicine (Baltimore) 2000;79(1):47-56.

[34] Zandman-Goddard G, Berkun Y, Barzilai O, et al. Neuropsychiatric lupus and infectious triggers. Lupus 2008;17(5):380-4.

[35] Cainelli F. Hepatitis C virus infection in the elderly: epidemiology, natural history and management. Drugs Aging 2008;25(1):9-18.

[36] Alter MJ. Epidemiology of hepatitis C virus infection. World J Gastroenterol 2007;13(17):2436-41.

[37] Kondili LA, Chionne P, Costantino A, et al. Infection rate and spontaneous seroreversion of anti-hepatitis $C$ virus during the natural course of hepatitis $C$ virus infection in the general population. Gut 2002;50(5):693-6.
[38] Robinson JW, Rosas M, Guzman F, Patarroyo ME, Moreno A. Comparison of prevalence of anti-hepatitis $C$ virus antibodies in differing South American populations. J Med Virol 1996;50(2):188-92.

[39] Ferri C. Mixed cryoglobulinemia. Orphanet J Rare Dis 2008;3:25.

[40] Antonelli A, Ferri C, Ferrari SM, Colaci M, Fallahi P. Immunopathogenesis of HCV-related endocrine manifestations in chronic hepatitis and mixed cryoglobulinemia. Autoimmun Rev 2008;8(1):18-23.

[41] Saadoun D, Landau DA, Calabrese LH, Cacoub PP. Hepatitis C-associated mixed cryoglobulinaemia: a crossroad between autoimmunity and lymphoproliferation. Rheumatology (Oxford) 2007;46(8):1234-42.

[42] Carrozzo M. Oral diseases associated with hepatitis $C$ virus infection. Part 1. sialadenitis and salivary glands lymphoma. Oral Dis 2008;14(2): 123-30.

[43] Indolfi G, Stagi S, Bartolini E, et al. Thyroid function and anti-thyroid autoantibodies in untreated children with vertically acquired chronic hepatitis $C$ virus infection. Clin Endocrinol (Oxf) 2008;68(1):117-21.

[44] Cacoub P, Renou C, Kerr G, et al. Influence of HLA-DR phenotype on the risk of hepatitis C virus-associated mixed cryoglobulinemia. Arthritis Rheum $2001 ; 44(9): 2118-24$.

[45] Tedeschi A, Barate C, Minola E, Morra E. Cryoglobulinemia. Blood Rev 2007;21(4):183-200.

[46] Lidar M, Lipschitz N, Langevitz P, et al. Infectious Serologies and Autoantibodies in Wegener's Granulomatosis and other Vasculitides: Novel Associations Disclosed Using the Rad BioPlex 2200. Ann N Y Acad Sci 2009.

[47] Ramos-Casals M, Forns X, Sanchez-Tapias JM. Extrahepatic Manifestations in Patients with Chronic Hepatitis C Virus Infection. In: Font Josep, RamosCasals Manuel, Juan Rodé S, Asherson RA, editors. Digestive Involvement in Systemic Autoimmune Diseases. Elsevier; 2008. p. 209-28.

[48] Antonelli A, Ferri C, Fallahi P, et al. Thyroid involvement in patients with overt HCV-related mixed cryoglobulinaemia. Qjm 2004;97(8):499-506.

[49] Antonelli A, Ferri C, Pampana A, et al. Thyroid disorders in chronic hepatitis C. Am J Med 2004;117(1):10-3.

[50] Tomer Y, Villanueva R. Hepatitis C and thyroid autoimmunity: is there a link? Am J Med 2004;117(1):60-1.

[51] Cassani F, Cataleta M, Valentini P, et al. Serum autoantibodies in chronic hepatitis C: comparison with autoimmune hepatitis and impact on the disease profile. Hepatology 1997;26(3):561-6.

[52] Garcia-Sastre A, Biron CA. Type 1 interferons and the virus-host relationship: a lesson in detente. Science 2006;312(5775):879-82.

[53] Krause I, Valesini G, Scrivo R, Shoenfeld Y. Autoimmune aspects of cytokine and anticytokine therapies. Am J Med 2003;115(5):390-7.

[54] Sagi L, Sherer Y, Trau H, Shoenfeld Y. Pemphigus and infectious agents. Autoimmun Rev 2008;8(1):33-5.

[55] Carrozzo M. Oral diseases associated with hepatitis C virus infection. Part 2: lichen planus and other diseases. Oral Dis 2008;14(3):217-28.

[56] Sherer Y, Blank M, Shoenfeld Y. Antiphospholipid syndrome (APS): where does it come from? Best Pract Res Clin Rheumatol 2007;21(6):1071-8.

[57] Garcia-Carrasco M, Galarza-Maldonado C, Mendoza-Pinto C, Escarcega RO, Cervera R. Infections and the Antiphospholipid Syndrome. Clin Rev Allergy Immunol 2008

[58] Blank M, Asherson RA, Cervera R, Shoenfeld Y. Antiphospholipid syndrome infectious origin. J Clin Immunol 2004;24(1):12-23.

[59] Munoz-Rodriguez FJ, Tassies D, Font J, et al. Prevalence of hepatitis C virus infection in patients with antiphospholipid syndrome. J Hepatol 1999;30(5):770-3.

[60] Ramos-Casals M, Cervera R, Lagrutta M, et al. Clinical features related to antiphospholipid syndrome in patients with chronic viral infections (hepatitis C virus/HIV infection): description of 82 cases. Clin Infect Dis 2004;38(7):1009-16

[61] Cervera R, Asherson RA, Acevedo ML, et al. Antiphospholipid syndrome associated with infections: clinical and microbiological characteristics of 100 patients. Ann Rheum Dis 2004;63(10):1312-7.

[62] Biancone L, Pavia M, Del Vecchio Blanco G, et al. Hepatitis B and C virus infection in Crohn's disease. Inflamm Bowel Dis 2001;7(4):287-94.

[63] Lidar M, Pnina Langevitz, Ori Barzilai, et al. Infectious Serologies and Autoantibodies in Inflammatory Bowel Disease: Insinuations at a True Pathogenic Role. In Press.

[64] Tilg H, Vogelsang H, Ludwiczek O, et al. A randomised placebo controlled trial of pegylated interferon alpha in active ulcerative colitis. Gut 2003;52(12):1728-33.

[65] Fox RI. Sjögren's syndrome. Lancet 2005;366(9482):321-31.

[66] Fattovich G, Tagger A, Brollo L, et al. Hepatitis $C$ virus infection in chronic hepatitis B virus carriers. J Infect Dis 1991;163(2):400-2.

[67] Gaeta GB, Stornaiuolo G, Precone DF, et al. Epidemiological and clinical burden of chronic hepatitis $B$ virus/hepatitis $C$ virus infection. A multicenter Italian study. J Hepatol 2003;39(6):1036-41.

[68] Park JS, Saraf N, Dieterich DT. HBV plus HCV, HCV plus HIV, HBV plus HIV. Curr Gastroenterol Rep 2006;8(1):67-74.

[69] Chu CJ, Lee SD. Hepatitis B virus/hepatitis C virus coinfection: epidemiology, clinical features, viral interactions and treatment. J Gastroenterol Hepatol 2008;23(4):512-20.

[70] Dai CY, Yu ML, Chuang WL, et al. Influence of hepatitis C virus on the profiles of patients with chronic hepatitis B virus infection. J Gastroenterol Hepatol 2001;16(6):636-40. 
[71] Xess A, Kumar M, Minz S, Sharma HP, Shahi SK. Prevalence of hepatitis B and hepatitis $C$ virus coinfection in chronic liver disease. Indian J Pathol Microbiol 2001;44(3):253-5.

[72] Tozzoli R, Barzilai O, Ram M, et al. Infections and autoimmune thyroid diseases: parallel detection of antibodies against pathogens with proteomic technology. Autoimmun Rev 2008;8(2):112-5.

[73] Buskila D, Sikuler E, Shoenfeld Y. Hepatitis C virus, autoimmunity and rheumatic disease. Lupus 1997;6(9):685-9.

[74] Akatsuka T, Kobayashi N, Ishikawa T, et al. Autoantibody response to microsomal epoxide hydrolase in hepatitis C and A. J Autoimmun 2007;28(1):7-18.
[75] Drygiannakis D, Lionis C, Drygiannakis I, Pappas G, Kouroumalis E. Low prevalence of liver-kidney microsomal autoantibodies of type 1 (LKM1) in hepatitis C seropositive subjects on Crete, Greece. BMC Gastroenterol $2001 ; 1: 4$

[76] Fried MW, Draguesku JO, Shindo M, et al. Clinical and serological differentiation of autoimmune and hepatitis $C$ virus-related chronic hepatitis. Dig Dis Sci38 1993;(4)::631-6.

[77] Shoenfeld Y, Gilburd B, Abu-Shakra M, et al. The mosaic of autoimmunity: genetic factors involved in autoimmune diseases-2008. Isr Med Assoc J 2008;10(1):3-7. 2008 